\title{
Evaluation of Environmental Awareness of University Students: the Case of the University of Presov, Slovakia
}

\author{
By Roman Novotný ${ }^{1}$, Emília Huttmanová ${ }^{1}$, Tomáš Valentiny ${ }^{1}$, Anna Kalistová ${ }^{2}$
}

\begin{abstract}
At present, all components of the environment are burdened by human activities. These human activities have caused many environmental problems, and without appropriate measures, they will have other far-reaching consequences in the future, which may be irreversible. One of the basic measures for the sustainable future of the environment and human society is to build the environmental awareness of the population. In addition to other entities, universities and their students and graduates have an important role in this process. The study focuses on the evaluation and comparison of environmental awareness and its factors among students of the University of Presov in Presov, Slovakia. Based on the results of this research, social networks and the internet are used as the main source of environmental information and should be used as a means of raising environmental awareness among students. The students of the University of Presov achieved high environmental awareness within the cognitive and emotional factors of environmental awareness, but they achieved only moderate environmental awareness within the behavioral factor. There were no significant differences in the level of environmental awareness between male and female students at the University of Presov. From the point of view of the group of study fields variable, significant differences were found in the emotional and behavioral factors of environmental awareness, with students of "Humanities" and "Natural Sciences, Mathematics and Informatics" achieving the highest scores and students of "Social, Economic and Legal Sciences" and "Healthcare" achieving the lowest scores.
\end{abstract}

Keywords: Environmental awareness, Environmental attitudes, Environmental behavior, University students, Slovakia

\section{Introduction}

Humans in their history always tried to use the benefits of the environment to meet their needs and improve their quality of life. Due to the over-exploitation of natural resources, the natural balance has gradually deteriorated, leading to serious environmental problems. These problems have taken on an international dimension as a result of technological progress and industrialization in recent decades (Gulgun et al. 2008). Environmental problems such as global warming, air pollution and ozone depletion have become global challenges. People have become estranged from nature because they perceive it as an infinite resource, making nature a tool for achieving anthropocentric goals. Unless people's view of nature changes, even laws and fines will not play the desired role. At this point, education plays a very important role (Karataş 2013). Environmental awareness, knowledge, attitudes and behavior of individuals are potential factors that can help address these challenges (Arshad et al. 2021). The aim of environmental awareness is

| ${ }^{1}$ Department of Environmental Management, Faculty of Management, University of Presov in Presov, Slovakia

${ }^{2}$ Institute of Social Sciences, Centre of Social and Psychological Sciences, Slovak Academy of Sciences, Košice, Slovakia 
to achieve appropriate knowledge and attitudes towards the environment and useful behavior towards the environment. Environmental knowledge can be explained as knowledge of environmental problems, the search for solutions to these problems and knowledge of ecological advances and all information about nature. Attitudes towards the environment relate to fear, anger, anxiety, value judgment and positive or negative attitudes of individuals towards useful behavior in solving environmental problems. Environmental behavior is effective and useful behavior for nature protection (Erten 2012).

Frankovský (2012) defined individual factors of environmental awareness when creating the DEP questionnaire methodology. The cognitive factor represents the thinking, analysis and search for information on environmental issues, i.e., it includes information and knowledge about environmental issues, interest in this information and at the same time their availability and sufficiency. The emotional factor represents an emotional response to environmental issues. Specifically, how a person experiences the facts of environmental issues, what attitudes, experiences and emotions evoke environmental issues and how a person can or cannot process them. The behavioral factor represents an immediate behavioral response: how a person at the level of behavior reacts to environmental problems, whether he is willing to do something concrete or only monitors the issue passively. Thus, the willingness to participate in the solution of individual environmental problems practically and specifically, the willingness to speak out in public for the protection of the environment, or the determination to join a group fighting for the environment.

Universities have an important role in the process of building environmental knowledge, attitudes and behavior, and should educate environmentally conscious students and graduates. It is of the utmost importance that universities develop environmental and sustainable environmental values. University students are expected to play active roles in their communities and professions upon graduation. One of their key roles is to convey the knowledge, skills, attitudes and values they have acquired during their university studies, to professional and personal life and to other environments. It is important to educate individuals who are concerned about environmental sustainability and knows how to prevent environmental problems (Şahin and Erkal 2017).

Measuring and assessing environmental awareness is essential to monitor and improve the environmental situation. A review of the literature revealed a lack of studies on the assessment of the environmental awareness of university students in the conditions of Slovakia. However, there are studies from the conditions of other countries.

Bozoglu et al. (2016) found that the average level of environmental awareness, attitudes and behavior of university students in Ondokuz Mayis University, Turkey, whose studies are somehow related to the environment, is high. Their findings confirmed that students' environmental attitudes and behaviors were generally influenced by the variable of the main source of environmental information. Gender had a very high impact on students' environmental awareness and behavior. Thus, female students were more interested in environmental issues and their probability of high environmental awareness was higher by $16.8 \%$ and probability of high environmental behavior was higher by $9.4 \%$ than male students. Age had an important impact on students' environmental awareness and attitudes, while age had no effect on students' environmental behavior. As they got older, their environmental awareness increased. However, with the increasing age of students, their environmental attitudes also decreased. Students from rural settlements had a higher 
environmental awareness than students from urban settlements. Although the mass media, as the main source of information, had an important positive impact on students' environmental awareness, they had a negative impact on their environmental behavior. Students' environmental awareness had the greatest positive impact on their environmental attitudes. Therefore, if students were more environmentally conscious, their attitudes would be more environmentally friendly. However, this study concluded that students who were more environmentally conscious would not be more environmentally friendly. Students' environmental attitudes had a very high positive impact on their environmental behavior. Therefore, if students had higher environmental attitudes, they would behave more environmentally friendly. However, the study concluded that students' environmental awareness is not sufficient for them to implement it in everyday life.

Arshad et al. (2020) concluded that university students from four universities in Pakistan had a high level of environmental awareness, environmental concerns and environmental behavior, but a very low level of environmental attitudes. The environmental awareness and environmental interests of university students contribute positively to the formation of their environmental behavior, but the environmental attitudes contribute negatively. There were significant differences in the levels of environmental awareness, concern, attitudes and behavior between students in the five academic disciplines (arts and humanities, social sciences, physical sciences, biological sciences and environmental sciences). The biological sciences were ranked at the top of environmental awareness, environmental attitudes, environmental concern and environmental behavior. Environmental sciences claimed second place in most cases, physical sciences in the third, arts and humanities in the fourth and social sciences in the last place in most cases.

A study by Heyl, Moyano Díaz and Cifuentes (2013) found that engineering students at a Chilean university had positive environmental attitudes, which are not reflected in the appropriate or proportional frequency of environmental behavior. They stated that there were no significant differences in environmental attitudes and behaviors in terms of degree or year of study. Longer study within the given curriculum had no effect on the attitudes and pro-environmental behavior of engineering students in this study. Gender differences were not confirmed in relation to the whole sample examined. The only existing gender differences were in attitudes towards the environment between first-year students, where women had more favorable attitudes towards the environment than men, but this difference disappeared as the study progressed. This differs from previous research by Tuncer et al. (2005). The results showed that gender and school type had a significant effect on collective dependent variables. In addition, there was a statistically significant mean difference between men and women in terms of scores in each dimension of the questionnaire. The study concluded that although there were differences between different categories of individuals, there is widespread support for environmental protection among university students living in Ankara, Turkey.

Yazici and Babalik (2016) conducted a study on a sample of students from the physical sciences, social sciences and health sciences programs, and found that although they had conceptual knowledge and awareness of environmental issues and the protection of natural resources, their attitudes and behaviors are not at the same level in their everyday life. The findings of this research show that there was a statistically significant difference between students' study departments and their attitude, awareness and sensitivity to the 
environment. In their research aimed at identifying environmental knowledge and sensitivity levels of university students, Talay et al. (2004) concluded, that the students had a generally acceptable level of environmental awareness and students of medical disciplines had a higher awareness of environmental issues than students of other study departments with a statistically significant difference. Different results were brought by the study conducted by Oguz et al. (2011), the environmental awareness and sensitivity levels of students at the Department of Landscape Architecture, Environmental Engineering, and City and Regional Planning were independent of students' study departments.

\section{Materials and Methods}

The study focuses on the evaluation and comparison of environmental awareness and its factors among students of the University of Presov in Presov, Slovakia The study used a survey technique to collect the data. The University of Presov has 8483 students studying within 8 faculties (University Portal 2021). The questionnaire contains 9 items for measuring the socio-demographic and identification characteristics of respondents, such as gender, residence, age, form of study, degree of study, faculty, group of study fields, study program and the main source of environmental information. A total of 443 students filled the questionnaire and participated in the study.

To determine the level of environmental awareness, the research used an adopted methodology for evaluating the attitudes of university students to selected areas of environmental awareness. It contains 45 items that have been adapted from the environmental awareness scales used in previous research (Bozoglu et al. 2016; Chan and Lau 2000; Heyl, Moyano Díaz and Cifuentes 2013; Frankovský 2012). These studies identified several environmental awareness factors, which are summarized in Table 1.

Table 1: Selected environmental awareness factors and number of measurement items in the constructed methodology

\begin{tabular}{ccc}
$\begin{array}{c}\text { Cognitive factor } \\
\text { (knowledge) }\end{array}$ & $\begin{array}{c}\text { Emotional factor } \\
\text { (attitudes) }\end{array}$ & $\begin{array}{c}\text { Behavioral factor } \\
\text { (behavior) }\end{array}$ \\
\hline
\end{tabular}

Number of items

in the constructed

15

15

15

methodology

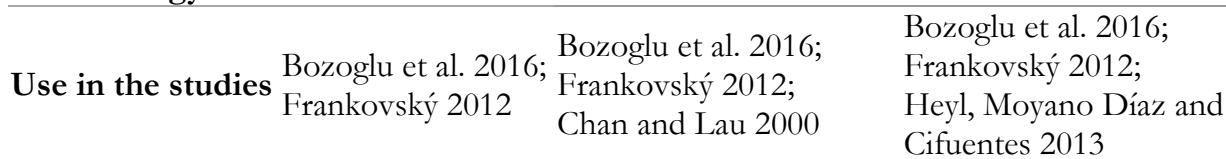

Source: own processing

Following the example of similar studies, a 5-point Likert scale is used to assess individual claims, with each item being assigned a score from 1 (strongly disagree) to 5 (strongly agree) (Chan and Lau 2000; Bozoglu et al. 2016). Items 7, 9, 10, 11, 15, 21, 27, 28, 29 and 39 need to be reversed. Respondents are divided into three groups according to their average score of answers to questions within individual factors. A respondent who scores less than 2.5 is assigned to a group with low environmental awareness, with a score of 2.5 to 3.5 to a group with moderate environmental awareness and respondents with a score 
greater than 3.5 are classified into a group with high environmental awareness within individual factors (Bozoglu et al. 2016).

The questionnaire was tested in advance and subsequently modified to increase its reliability. Questionnaires were filled out by students at the time of online learning caused by the coronavirus in December 2020. As for the methods of analysis of the obtained data, they were evaluated in the statistical programs SPSS Statistics 27.0.1.0 and R 4.0.3.

\section{Results and Discussion}

Table 2 provides a summary of the processed data obtained from the part of the questionnaire, which contains questions for evaluating the socio-demographic profile of the sample population. When obtaining data using questionnaires, the frequency within the individual categories was targeted at the socio-demographic situation of students of the University of Presov, which is determined by the Annual Report on the Activities of the University of Presov in Presov in 2019 (University of Presov in Presov 2020). The population studied in this research includes students from all 8 faculties in the 1 st, 2 nd and 3rd degree of study and in both full-time and part-time form. Therefore, the respondent sample portrays a comprehensive profile of students of the University of Presov. The mean age of respondents was 23.1 years, the minimum age reached 18 years and the maximum age reached 58 years. Respondents are divided into 47 study programs within 5 groups of study fields (selected according to University Portal 2021).

Table 2: Descriptive statistics related to the sample of students of the University of Presov

\begin{tabular}{llcc}
\hline Variable & Category & Frequency & Percent \\
\hline Gender & Male & 170 & 38.4 \\
& Female & 273 & 61.6 \\
& Total & 443 & 100.0 \\
\hline Residence & Rural area & 226 & 51.0 \\
& City up to 10,000 inhabitants & 41 & 9.3 \\
& City from 10,001 to 100,000 inhabitants & 137 & 30.9 \\
& City with more than 100,000 inhabitants & 39 & 8.8 \\
& Total & 443 & 100.0 \\
\hline Form of study & Full-time & 395 & 89.2 \\
& Part-time & 48 & 10.8 \\
& Total & 443 & 100.0 \\
\hline Degree of study & 1. (Bachelor's) & 288 & 65.0 \\
& 2. (Master's) & 133 & 30.0 \\
& 3. (Doctoral) & 22 & 5.0 \\
& Total & 443 & 100.0 \\
\hline Faculty & Faculty of Humanities and Natural Sciences & 71 & 16.0 \\
& Faculty of Management & 77 & 17.4 \\
& Faculty of Sports & 40 & 9.0 \\
& Faculty of Health Care & 58 & 13.1 \\
& Faculty of Arts & 69 & 15.6 \\
& Greek-Catholic Theological Faculty & 30 & 6.8 \\
& Faculty of Education & 67 & 15.1 \\
& Faculty of Orthodox Theology & 31 & 7.0 \\
& Total & 443 & 100.0 \\
\hline & & &
\end{tabular}




\begin{tabular}{llcc}
\hline Variable & Category & Frequency & Percent \\
\hline Group of study fields Humanities & 54 & 12.2 \\
& Natural Sciences, Mathematics and Informatics & 40 & 9.0 \\
& Social, Economic and Legal Sciences & 99 & 22.3 \\
& Education & 164 & 37.0 \\
& Healthcare & 86 & 19.4 \\
Total & 443 & 100.0 \\
\hline
\end{tabular}

Source: own processing

Table 3 shows the descriptive statistics on the main source of environmental information. Social networks are above all the main sources, internet pages rank second and television (news, films and documentaries) ranks third. The radio was marked as a primary source by the least respondents. According to Special Eurobarometer 501, the most interesting observation in its overall results from 2019 survey is the evolution of social networks, the internet and the radio (European Commission 2020). The radio was found among the top three sources together with television (news, films and documentaries) and newspapers in Eurobarometer survey from 2004 (European Commission 2005). However, social networks and the internet rank as the second most used source in 2019 and the radio is not among the top three sources anymore. In every country, television news was most likely to be mentioned as the main source of environmental information. Based on the results of this research, when targeting specifically student populations it is highly recommendable to consider the social networks and the internet as a means of raising awareness.

Table 3: Descriptive statistics on the main source of environmental information

\begin{tabular}{clcc}
\hline Variable & Category & Frequency & Percent \\
\hline Main source of environmental information & Films and documentaries & 54 & 12.2 \\
& Internet pages & 102 & 23.0 \\
& Books or scientific publications & 16 & 3.6 \\
Newspapers and magazines & 15 & 3.4 \\
& Radio & 1 & 0.2 \\
& Family and acquaintances & 7 & 1.6 \\
& Social networks & 202 & 45.6 \\
Television news & 46 & 10.4 \\
Total & 443 & 100.0 \\
\hline
\end{tabular}

Source: own processing

The structure of theoretically defined environmental awareness factors was verified using confirmatory factor analysis (CFA). Brown (2006) provides recommendations that were taken into account in the CFA analysis and suggests the following categories of model fit indices: "standardized root mean square residual" (SRMR), root mean square error of approximation (RMSEA), Tucker-Lewis index (TLI) and Comparative Fit Index (CFI). The examined sample is relatively large, so the chi-square test is not an optimal indicator of the suitability of the model and the ratio of the chi-square statistic to the respective degrees of freedom $\left(\chi^{2} / \mathrm{df}\right)$ is preferred (Bentler 1990, Wheaton et al. 1977). The required condition is that this ratio is smaller than 3 (Bollen 1989). The following cut-off values 
were used to indicate model fit: TLI and CFI $\geq 0.90$ (Hu and Bentler 1995), RMSEA and SRMR $\leq 0.08$ (Brown 2006). Convergent validity was assessed by Factor loadings $\geq 0.5$ (Hair et al. 2009). The used model proved to be acceptable to good after adjustments within items, with $\chi^{2} / \mathrm{df}=2.11$; CFI $=0.911$; TLI $=0.905$; RMSEA $=0.050(90 \%$ confidence interval $0.46-0.54$ ) and SRMR 0.049. The values are shown in Table 4.

Table 4: Model fit indices

\begin{tabular}{lc}
\hline Index & Value \\
\hline$\chi^{2}$ & 1175.463 \\
$\mathrm{df}$ & 557 \\
$\chi^{2} / \mathrm{df}$ & 2.11 \\
$\mathrm{CFI}$ & 0.911 \\
TLI & 0.905 \\
RMSEA & 0.050 \\
RMSEA 90\% CI lower bound & 0.046 \\
RMSEA 90\% CI upper bound & 0.054 \\
SRMR & 0.049 \\
\hline
\end{tabular}

Source: own processing

For determining whether items of confirmed factors were consistent with each other or not, Cronbach's alpha internal consistency coefficient was calculated. Considering the results of the CFA, reliability analysis was performed for each factor. Each analysis revealed sufficient results. Cronbach's alpha reliability coefficient $(\alpha)$ of the first factor "Cognitive factor" (C) - with nine items was found to be 0.868 , reliability $(\alpha)$ of the second factor - "Emotional factor" (E) - with thirteen items was found to be 0.912, and reliability $(\alpha)$ of the third factor - "Behavioral factor" (B) - with thirteen items was found to be 0.889 .

Table 5 summarizes the factor loadings and reliability of each factor.

Table 5: Factor loadings and Cronbach's alpha for each factor of environmental awareness

\begin{tabular}{|c|c|c|c|c|c|c|c|}
\hline \multirow{2}{*}{\multicolumn{3}{|c|}{ Factor Indicator Estimate }} & \multirow[b]{2}{*}{$\begin{array}{l}\text { Std. } \\
\text { Error }\end{array}$} & \multirow[b]{2}{*}{$\begin{array}{c}\mathrm{z}- \\
\text { value }\end{array}$} & \multicolumn{2}{|c|}{ 95\% Confidence Interval } & \multirow[b]{2}{*}{$\begin{array}{l}\text { Cronbach's } \\
\text { alpha }\end{array}$} \\
\hline & & & & & Lower & Upper & \\
\hline \multirow[t]{9}{*}{ Factor1 } & $\mathrm{C} 1$ & 0.616 & 0.038 & 16.030 & 0.541 & 0.692 & 0.868 \\
\hline & $\mathrm{C} 4$ & 0.575 & 0.045 & 12.690 & 0.486 & 0.664 & \\
\hline & C5 & 0.519 & 0.044 & 11.698 & 0.432 & 0.606 & \\
\hline & C6 & 0.671 & 0.039 & 17.386 & 0.595 & 0.746 & \\
\hline & $\mathrm{C} 7 \mathrm{r}$ & 0.535 & 0.041 & 13.046 & 0.454 & 0.615 & \\
\hline & C12 & 0.745 & 0.038 & 19.734 & 0.671 & 0.819 & \\
\hline & C13 & 0.612 & 0.047 & 12.904 & 0.519 & 0.705 & \\
\hline & C14 & 0.630 & 0.038 & 16.545 & 0.555 & 0.704 & \\
\hline & $\mathrm{C} 15 \mathrm{r}$ & 0.608 & 0.041 & 14.898 & 0.528 & 0.688 & \\
\hline \multirow[t]{6}{*}{ Factor2 } & E1 & 0.620 & 0.042 & 14.775 & 0.538 & 0.703 & 0.912 \\
\hline & $\mathrm{E} 2$ & 0.734 & 0.041 & 18.063 & 0.654 & 0.813 & \\
\hline & E3 & 0.505 & 0.041 & 12.233 & 0.424 & 0.586 & \\
\hline & E4 & 0.619 & 0.041 & 15.265 & 0.539 & 0.698 & \\
\hline & E5 & 0.634 & 0.040 & 15.960 & 0.556 & 0.711 & \\
\hline & E6r & 0.585 & 0.043 & 13.679 & 0.501 & 0.669 & \\
\hline
\end{tabular}




\begin{tabular}{|c|c|c|c|c|c|c|c|}
\hline \multirow{2}{*}{\multicolumn{3}{|c|}{ Factor Indicator Estimate }} & \multirow[b]{2}{*}{$\begin{array}{l}\text { Std. } \\
\text { Error }\end{array}$} & \multirow[b]{2}{*}{$\begin{array}{c}\mathrm{z}- \\
\text { value }\end{array}$} & \multicolumn{2}{|c|}{ 95\% Confidence Interval } & \multirow[b]{2}{*}{$\begin{array}{c}\text { Cronbach's } \\
\text { alpha }\end{array}$} \\
\hline & & & & & Lower & Upper & \\
\hline & E7 & 0.638 & 0.043 & 14.947 & 0.554 & 0.721 & \\
\hline & E8 & 0.737 & 0.040 & 18.448 & 0.658 & 0.815 & \\
\hline & E9 & 0.709 & 0.040 & 17.844 & 0.632 & 0.787 & \\
\hline & E10 & 0.734 & 0.041 & 17.935 & 0.653 & 0.814 & \\
\hline & E11 & 0.692 & 0.046 & 14.880 & 0.601 & 0.783 & \\
\hline & E13r & 0.615 & 0.041 & 14.898 & 0.534 & 0.696 & \\
\hline & E15 & 0.564 & 0.040 & 14.060 & 0.485 & 0.642 & \\
\hline \multirow[t]{13}{*}{ Factor3 } & B1 & 0.592 & 0.045 & 13.193 & 0.504 & 0.680 & 0.889 \\
\hline & B2 & 0.548 & 0.047 & 11.754 & 0.457 & 0.640 & \\
\hline & B3 & 0.609 & 0.048 & 12.605 & 0.514 & 0.704 & \\
\hline & B4 & 0.655 & 0.042 & 15.624 & 0.573 & 0.737 & \\
\hline & B6 & 0.577 & 0.044 & 13.068 & 0.490 & 0.663 & \\
\hline & B7 & 0.624 & 0.044 & 14.237 & 0.538 & 0.710 & \\
\hline & B8 & 0.655 & 0.046 & 14.214 & 0.564 & 0.745 & \\
\hline & B10 & 0.619 & 0.050 & 12.331 & 0.521 & 0.717 & \\
\hline & B11 & 0.661 & 0.045 & 14.831 & 0.574 & 0.748 & \\
\hline & B12 & 0.574 & 0.042 & 13.776 & 0.492 & 0.656 & \\
\hline & B13 & 0.605 & 0.041 & 14.934 & 0.526 & 0.684 & \\
\hline & B14 & 0.755 & 0.049 & 15.486 & 0.659 & 0.851 & \\
\hline & B15 & 0.732 & 0.049 & 14.998 & 0.636 & 0.828 & \\
\hline
\end{tabular}

Source: own processing

Table 6 shows the items included in the factor model, along with their basic descriptive characteristics. According to the resulting values of mean, median and mode, it is visible that the lowest scores were achieved by students of the University of Presov in items of behavioral factor (31-45). The best average results for this factor, which reached scores greater than 3.5, were achieved in items dealing with paying attention to waste separation, the careful use of resources such as water and electricity, political support for environmental issues and support for environmental protection measures. In the case of the emotional factor, a score of less than 3.5 was achieved within one item, specifically within the item about high sensitivity in regard to environmental issues.

Table 6: The final composition of items within the factor model and their descriptive characteristics

Statements

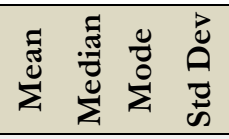

1. Awareness of environmental issues helps to improve the implementation of environmental activities.

$\begin{array}{llll}4.3 & 4 & 5 & 0.89\end{array}$

4. Very little space is devoted to environmental information in the media.

$3.99 \quad 4 \quad 4 \quad 1.00$

5. I need more information about the effects of human activities on the environment.

$\begin{array}{llll}3.79 & 4 & 4 & 0.97\end{array}$

6. Mankind treats the environment inappropriately.

$\begin{array}{llll}4.47 & 5 & 5 & 0.91\end{array}$

$7 \mathrm{r}$. The use of chemicals in agriculture is not harmful to the environment.

$\begin{array}{llll}4.36 & 5 & 5 & 0.91\end{array}$

12. In order for future generations to live in a healthy and safe environment, it is essential to educate environmentally friendly individuals.

$\begin{array}{llll}4.54 & 5 & 5 & 0.93\end{array}$ 


\begin{tabular}{|c|c|c|c|c|}
\hline Statements & $\sum_{\tilde{\Sigma}}^{\tilde{J}}$ & 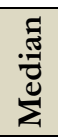 & $\overbrace{}^{0}$ & $\begin{array}{l}\text { ¿ } \\
\text { D } \\
\text { D }\end{array}$ \\
\hline 13. In Slovakia, environmental education and upbringing are not sufficient. & 3.92 & 4 & 5 & 1.05 \\
\hline $\begin{array}{l}\text { 14. The provision of environmental education and upbringing helps to solve } \\
\text { environmental problems. }\end{array}$ & 4.22 & 4 & 5 & 0.89 \\
\hline $\begin{array}{l}\text { 15r. Environmental education and upbringing activities are only useful for } \\
\text { children. }\end{array}$ & 4.24 & 4 & 5 & 0.93 \\
\hline 16. I am disappointed that people are not interested in the environment. & 4.16 & 4 & 5 & 0.97 \\
\hline 17. I am worried about the future of the environment. & 4.21 & 4 & 5 & 0.98 \\
\hline 18. I think I am very sensitive about environmental issues. & 3.43 & 3 & 3 & 0.92 \\
\hline outcide the city moles me handy & 4.37 & 5 & 5 & 0.94 \\
\hline 20. People who pollute the et & 4.43 & 5 & 5 & 0.93 \\
\hline $\begin{array}{l}21 \mathrm{r} \text {. I am angry at the activities of organizations fighting to protect the } \\
\text { environment. }\end{array}$ & 4.18 & 5 & 5 & 0.97 \\
\hline $\begin{array}{l}\text { 22. I am angry when I think about the damage to plants and animals caused by } \\
\text { pollution. }\end{array}$ & 3.97 & 4 & 4 & 0.99 \\
\hline $\begin{array}{l}\text { 23. I am frustrated when I think about how industries cause environmental } \\
\text { pollution. }\end{array}$ & 4.02 & 4 & 4 & 0.97 \\
\hline 24. I am concerned that dangerous chemicals are used in food production. & 4.27 & 5 & 5 & 0.96 \\
\hline $\begin{array}{l}\text { 25. I am annoyed at the idea that the government is not doing more to help } \\
\text { control environmental pollution. }\end{array}$ & 4.14 & 4 & 5 & 0.99 \\
\hline $\begin{array}{l}\text { 26. I am concerned about any country involved in nuclear testing, regardless of } \\
\text { its status. }\end{array}$ & 3.92 & 4 & 5 & 1.07 \\
\hline $\begin{array}{l}\text { mental pollution has never bothered me too much, } \\
\text { ated. }\end{array}$ & 4.16 & 4 & 5 & 0.95 \\
\hline $\begin{array}{l}\text { 30. Measures to protect the environment give me more joy than measures to } \\
\text { ensure economic development. }\end{array}$ & 3.63 & 4 & 4 & 0.91 \\
\hline 31. I am actively looking for & 3.17 & 3 & 3 & 1.00 \\
\hline 32. I parti & 3.01 & 3 & 2 & 1.02 \\
\hline 33. I would be willing to speak out in public to & 3.25 & 3 & 3 & 1.07 \\
\hline $\begin{array}{l}\text { 34. I would support measures to protect the environment, even if it would } \\
\text { reduce my living comfort. }\end{array}$ & 3.74 & 4 & 4 & 0.97 \\
\hline 36. I support politicians who deal with environmental issues. & 3.82 & 4 & 4 & 0.98 \\
\hline 37. In ever & 4.03 & 4 & 5 & 0.99 \\
\hline 38. I usually use resources such as water and electricity sparingly. & 3.89 & 4 & 4 & 1.04 \\
\hline 40. I usually use public tra & 3.47 & 4 & 4 & 1.10 \\
\hline $\begin{array}{l}\text { 41. I avoid using products produced by a company known to pollute the } \\
\text { environment. }\end{array}$ & 3.19 & 3 & 3 & 1.02 \\
\hline 42. I buy products with an ecological certificate. & 3.08 & 3 & 3 & 0.94 \\
\hline 43. In everyday life, I buy 1 & 3.2 & 3 & 3 & 0.92 \\
\hline 44. I prefer to drink beverages that are in returnable bottles. & 3.43 & 3 & 4 & 1.12 \\
\hline $\begin{array}{l}\text { 45. When deciding to purchase two similar products, I tend to } \\
\text { that has less harmful effects on the environment. }\end{array}$ & 3. & 4 & 4 & 1.12 \\
\hline
\end{tabular}

Source: own processing

According to the levels of environmental awareness, the division of which is given in the methodology, students of the University of Presov achieved a high level of environmental awareness within the cognitive and emotional factors. Another situation occurred with the 
behavioral factor, where the results of the respondents' answers indicate a slightly worse result - a score of moderate environmental awareness. For the categories of the "gender" variable, the results did not differ significantly from the results of the whole sample. In the variable "group of study fields", it was shown that students within the categories of "Humanities", "Natural Sciences, Mathematics and Informatics" and "Education" achieved a high level of environmental awareness also within the behavioral factor. The average results of the individual categories are shown in Table 7.

Table 7: Mean scores of factors of environmental awareness for the whole sample, categories of gender and each group of study fields

\begin{tabular}{|c|c|c|c|c|}
\hline Category & Frequency & Factor & Mean & Std. Deviation \\
\hline \multirow{3}{*}{ Whole sample } & \multirow{3}{*}{443} & $\mathrm{C}$ & 4.20 & 0.65 \\
\hline & & E & 4,07 & 0.67 \\
\hline & & B & 3,44 & 0.67 \\
\hline \multirow{3}{*}{ Male } & \multirow{3}{*}{170} & $\mathrm{C}$ & 4.16 & 0.66 \\
\hline & & E & 4.01 & 0.68 \\
\hline & & B & 3.40 & 0.65 \\
\hline \multirow{3}{*}{ Female } & \multirow{3}{*}{273} & $\mathrm{C}$ & 4.23 & 0.65 \\
\hline & & $\mathrm{E}$ & 4.10 & 0.67 \\
\hline & & B & 3.47 & 0.68 \\
\hline \multirow{3}{*}{ Humanities } & \multirow{3}{*}{54} & $\mathrm{C}$ & 4.26 & 0.58 \\
\hline & & E & 4.18 & 0.67 \\
\hline & & B & 3.61 & 0.62 \\
\hline \multirow{3}{*}{ Natural Sciences, Mathematics and Informatics } & \multirow{3}{*}{40} & $\mathrm{C}$ & 4.31 & 0.40 \\
\hline & & $\mathrm{E}$ & 4.11 & 0.42 \\
\hline & & B & 3.61 & 0.48 \\
\hline \multirow{3}{*}{ Social, Economic and Legal Sciences } & \multirow{3}{*}{99} & $\mathrm{C}$ & 4.16 & 0.79 \\
\hline & & $\mathrm{E}$ & 3.95 & 0.81 \\
\hline & & B & 3.32 & 0.76 \\
\hline \multirow{3}{*}{ Education } & \multirow{3}{*}{164} & $\mathrm{C}$ & 4.26 & 0.46 \\
\hline & & E & 4.15 & 0.51 \\
\hline & & B & 3.52 & 0.57 \\
\hline \multirow{3}{*}{ Healthcare } & \multirow{3}{*}{86} & $\mathrm{C}$ & 4.06 & 0.90 \\
\hline & & $\mathrm{E}$ & 3.97 & 0.84 \\
\hline & & B & 3.24 & 0.78 \\
\hline
\end{tabular}

Source: own processing

Based on the nature of the data (non-normal distribution according to the Shapiro-Wilk test and Histogram analysis), the Mann-Whitney $U$ test is used to analyze the significance of differences in environmental awareness factors between the various categories of the gender and the group of study fields. For the gender variable, we wanted to verify the results of studies that found that there are no significant differences between the categories of male and female. The results of the test confirmed that there are no significant differences between male and female students at the University of Presov. Similar results were obtained by the study of Heyl, Moyano Díaz and Cifuentes (2013), in which no significant differences in environmental awareness factors were confirmed within the 
gender of respondents. The study by Hailu (2016) also found no statistically significant difference in attitudes towards the environment between male and female respondents. The results of the analysis are shown in Table 8.

Table 8: Results of the Mann-Whitney U test according to the variable "gender"

\begin{tabular}{|c|c|c|c|c|c|c|c|c|}
\hline Factor & Gender & $\mathbf{N}$ & $\begin{array}{l}\text { Mean } \\
\text { Rank }\end{array}$ & $\begin{array}{l}\text { Sum of } \\
\text { Ranks }\end{array}$ & $\begin{array}{c}\text { Mann-Whitney } \\
\text { U }\end{array}$ & $\begin{array}{c}\text { Wilcoxon } \\
\text { W }\end{array}$ & $\mathrm{Z}$ & $\begin{array}{l}\text { Asymp. } \\
\text { Sig. }\end{array}$ \\
\hline \multirow{2}{*}{$\mathrm{C}$} & Male & 170 & 210.01 & 35701.00 & \multirow{2}{*}{21166.000} & \multirow{2}{*}{35701.000} & \multirow{2}{*}{-1.563} & \multirow{2}{*}{0.118} \\
\hline & Female & 273 & 229.47 & 62645.00 & & & & \\
\hline \multirow{2}{*}{$\mathrm{E}$} & Male & 170 & 209.43 & 35603.00 & \multirow{2}{*}{21068.000} & \multirow{2}{*}{35603.000} & \multirow{2}{*}{-1.633} & \multirow{2}{*}{0.103} \\
\hline & Female & 273 & 229.83 & 62743.00 & & & & \\
\hline \multirow{2}{*}{ B } & Male & 170 & 213.16 & 36238.00 & \multirow{2}{*}{21703.000} & \multirow{2}{*}{36238.000} & \multirow{2}{*}{-1.147} & \multirow{2}{*}{0.251} \\
\hline & Female & 273 & 227.50 & 62108.00 & & & & \\
\hline
\end{tabular}

Source: own processing

We found that there are significant differences in factors of environmental awareness between the categories of the group of study fields variable. For the emotional factor (E), a significant difference was found only when comparing "the Humanities" with "the Social, Economic and Legal Sciences" category. For the behavioral factor (B), the most significant differences were achieved according to the p-value $<0.01$ when comparing "the Humanities" with "the Healthcare" category. Differences significant at the $\mathrm{p}$-value $<0.05$ were detected when comparing: 1. "the Humanities" with "the Social, Economic and Legal Sciences"; 2. and 3. "the Natural Sciences, Mathematics and Informatics" with "the Social, Economic and Legal Sciences" and "the Healthcare"; and 4. "the Education" with "the Healthcare". The results of the analysis that reached the desired significance values are shown in Table 9.

Table 9: Results of the Mann-Whitney $U$ test according to the variable "group of study fields"

\begin{tabular}{|c|c|c|c|c|c|c|c|c|}
\hline \multicolumn{2}{|c|}{ Factor Group of study fields } & $\mathbf{N}$ & $\begin{array}{l}\text { Mean } \\
\text { Rank }\end{array}$ & $\begin{array}{l}\text { Sum of } \\
\text { Ranks }\end{array}$ & $\begin{array}{c}\text { Mann- } \\
\text { Whitney U }\end{array}$ & $\begin{array}{c}\text { Wilcoxon } \\
\text { W }\end{array}$ & $\mathrm{Z}$ & $\begin{array}{c}\text { Asymp. } \\
\text { Sig. }\end{array}$ \\
\hline \multirow[b]{2}{*}{$\mathrm{E}$} & Humanities & 54 & 86.62 & 4677.50 & \multirow[b]{2}{*}{2153.500} & \multirow[b]{2}{*}{7103.500} & \multirow[b]{2}{*}{-1.986} & \multirow[b]{2}{*}{0.047} \\
\hline & $\begin{array}{l}\text { Social, Economic and Legal } \\
\text { Sciences }\end{array}$ & 99 & 71.75 & 7103.50 & & & & \\
\hline \multirow{10}{*}{ B } & Humanities & 54 & 87.82 & 4742.50 & \multirow[b]{2}{*}{2088.500} & \multirow[b]{2}{*}{7038.500} & \multirow[b]{2}{*}{-2.234} & \multirow[b]{2}{*}{0.026} \\
\hline & $\begin{array}{l}\text { Social, Economic and Legal } \\
\text { Sciences }\end{array}$ & 99 & 71.10 & 7038.50 & & & & \\
\hline & Humanities & 54 & 82.14 & 4435.50 & \multirow{2}{*}{1693.500} & \multirow{2}{*}{5434.500} & \multirow{2}{*}{-2.695} & \multirow{2}{*}{0.007} \\
\hline & Healthcare & 86 & 63.19 & 5434.50 & & & & \\
\hline & $\begin{array}{l}\text { Natural Sciences, } \\
\text { Mathematics and Informatics }\end{array}$ & 40 & 81.33 & 3253.00 & \multirow{2}{*}{1527.000} & \multirow{2}{*}{6477.000} & \multirow{2}{*}{-2.110} & \multirow{2}{*}{0.035} \\
\hline & $\begin{array}{l}\text { Social, Economic and Legal } \\
\text { Sciences }\end{array}$ & 99 & 65.42 & 6477.00 & & & & \\
\hline & $\begin{array}{l}\text { Natural Sciences, } \\
\text { Mathematics and Informatics }\end{array}$ & 40 & 75.65 & 3026.00 & \multirow[t]{2}{*}{1234.000} & \multirow[t]{2}{*}{4975.000} & \multirow[t]{2}{*}{-2.551} & \multirow[t]{2}{*}{0.011} \\
\hline & Healthcare & 86 & 57.85 & 4975.00 & & & & \\
\hline & Education & 164 & 132.59 & 21745.50 & \multirow{2}{*}{5888.500} & \multirow{2}{*}{9629.500} & \multirow{2}{*}{-2.144} & \multirow{2}{*}{0.032} \\
\hline & Healthcare & 86 & 111.97 & 9629.50 & & & & \\
\hline
\end{tabular}

Source: own processing 
The group of study fields is thus a variable that determines the differences in the level of environmental awareness of the students of the University of Presov in Presov. Similar results are described by the study of Arshad et al. (2020), where biological sciences students achieved the best score and social sciences students achieved the worst score. The existence of a statistically significant difference in environmental attitudes, awareness and sensitivity between students' study departments is confirmed also by Yazici and Babalik (2016).

\section{Conclusion}

The study focused on the evaluation and comparison of environmental awareness and its factors among students of the University of Presov in Presov, Slovakia. Based on the results of this research, social networks and the internet are used as the main source of environmental information and should be used as a means of raising environmental awareness among students. According to the results, students of the University of Presov in Presov achieved high environmental awareness within the cognitive and emotional factors, but within the behavioral factor they achieved only moderate environmental awareness. Results also showed that there were no significant differences in the level of environmental awareness between male and female students at the University of Presov, which confirms the findings of several studies in higher education conditions. From the point of view of the group of study fields variable, significant differences were found in the emotional factor in one case and in the behavioral factor in five cases, with students of "Humanities" and "Natural Sciences, Mathematics and Informatics" achieving the highest results and students of "Social, Economic and Legal Sciences" and "Healthcare" achieving the lowest results.

Within the questionnaire, students had the opportunity to express their opinion on improving the situation in the field of environmental awareness in the environment of universities, and some of the listed proposals are formulated on the basis of their perspective. As part of environmental awareness-raising activities, it is necessary to include university information campaigns in the field of public transport use, recycling, energy efficiency, etc., which could be organized as part of teaching, especially by students of environmental disciplines and environmentally engaged teachers and students, for example as university-wide events within the Earth Day, World Water Day, International Day for Biological Diversity, etc., and these campaigns could include practical activities such as organizing garbage collection around the university and planting trees. They could be complemented by university-wide lectures by environmental experts. These information campaigns need to involve resources in the framework of the internet and social networks, which are important with regard to environmental information according to research results. An interesting connection of various beneficial activities is offered by the promotion of a new sports trend with good environmental impact named "plogging", the activity of picking up trash while jogging, or the promotion of a generally beneficial environmental activity - beekeeping in the nearby exterior of the school. An important step would be the inclusion of the university-wide optional subject Environmental Education or the inclusion of environmental topics in the syllabi of compulsory subjects. Universities should provide the possibility of students participating in environmental 
scientific activities, such as conferences, panels and seminars, in particular with the participation of practitioners who can clarify the situation and solutions to various environmental problems in practice. Universities should also identify themselves more as "green" and try to evoke in students a sense of belonging and the need to adhere to the principles of their university. After implementing these steps, students could better identify environmental problems and take the necessary preventive measures at a better level.

The study can be further developed to include other factors that were not taken into account in the current study. In addition, the data collection tool used in this study can be used to include different variables or compare university students from different universities, students from other countries or high school students, in order to make comparisons between the results of different groups.

\section{Acknowledgments}

This paper is supported by GaPU 31/2020, VEGA 1/0578/18 "Modification of the Methodologies for the Sustainable Development Assessment", KEGA 038PU-4/2018 "Development of the Study Program Environmental Management in the II. Degree of Study" and KEGA 024PU-4/2020 "Innovation of the Structure, Content and the Method of Teaching the Economic Subjects for the Study Program Entitled Management and Environmental Management of the Doctoral Degree of the Study".

\section{References}

Arshad, H. M., Saleem, K., Shafi, S., Ahmad, T., Kanwal, S. (2021). Environmental Awareness, Concern, Attitude and Behavior of University Students: A Comparison Across Academic Disciplines. Polish Journal of Environmental Studies, 30(1), 561-570.

Bentler, P.M. (1990). Comparative fit indexes in structural models. Psychological Bulletin, 107(2), 238-246.

Bollen, K.A. (1989). Structural equations with latent variables. New York: Wiley.

Bozoglu, M., Bilgic, A., Topuz, B.K., Ardali, Y. (2016). Factors affecting the students' environmental awareness, attitudes and behaviors in Ondokuz Mayis University, Turkey. Fresenius Environmental Bulletin, 25(4), 1243-1257.

Brown, T.A. (2006). Confirmatory factor analysis for applied research. New York: Guilford Press.

Erten, S. (2012). Environmental Consciousness among Turkish and Azeri Candidate Teachers. Education and Science, 37(166), 88-100.

European Commission (2005). Special Eurobarometer 217. The attitudes of European citizens towards environment. https://ec.europa.eu/commfrontoffice/publicopinion/archives/ebs/ebs_217_en.pdf Accessed January $25,2021$.

European Commission (2020). Special Eurobarometer 501. Attitudes of European citizens towards the environment. https://data.europa.eu/euodp/en/data/dataset/S2257_92_4_501_ENG Accessed January 24, 2021.

Frankovský, M. (2012). Možnosti zist'ovania environmentálneho povedomia. Journal of Management and Business: Research and Practice, 4(1), 7-14.

Gulgun, B., Onder, S., Aktas, E., Unal Akkaya, F. (2008). Responses of university students related to environmental problems: a case study of Ege University (Izmir-Turkey). Journal of International Environmental Application \& Science, 3(4), 234-246.

Hailu, F. (2016). Knowledge, Attitudes and Practice of Bahir Dar University Undergraduate Students towards Environmental Issues. Eastern Africa Social Science Research Review, 32(2), 87-102.

Hair, J.F., Black, W.C., Babin, B.J., Anderson, R.E. (2009). Multivariate data analysis (7th ed.). New Jersey: Pearson Prentice Hall. 
Heyl, M., Moyano Díaz, E., Cifuentes, L. (2013). Environmental attitudes and behaviors of college students: a case study conducted at a chilean university. Revista Latinoamericana de Psicología,. 45(3), 487-500.

Hu, L.T., Bentler P.M. (1995). Evaluating model fit. In: Hoyle, R.H., eds. Structural equation modeling: Concepts, issues, and applications. Thousand Oaks, CA: Sage Publications, 76-99.

Chan, R.Y., Lau, L.B. (2000). Antecedents of green purchases: a survey in China. Journal of consumer marketing, 17(4), 338-357.

Karataş, A. (2013). The role of faculties of education in increasing sustainable environmental awareness of society. European Journal of Sustainable Development, 2(4), 233-242.

Oguz, D., Cakıc1, I., Kavas, S. (2011). Students' environmental consciousness in higher education. Turkish Journal of Forestry, 12(1), 34-39.

Şahin, H., Erkal, S. (2017). An Investigation of University Students' Attitudes Toward Environmental Sustainability. European Journal of Sustainable Development, 6(4), 147-154.

Talay, I., Gunduz, S., Akpinar, N. (2004). On the status of environmental education and awareness of undergraduate students at Ankara University, Turkey. International Journal of Environment and Pollution, 21(3), 293-308.

Tuncer, G., Ertepinar, H., Tekkaya, C., Sungur, S. (2005). Environmental attitudes of young people in Turkey: Effects of school type and gender. Environmental Education Research, 11(2), 215-233.

University of Presov in Presov (2020). The Annual Report on the Activities of the University of Prešov in Prešov in 2019. Presov: University of Presov in Presov.

University Portal (2021). Group fields of study. https://www.portalvs.sk/en/studijne-odbory Accessed January 22, 2021.

University Portal (2021). Register of universities by number of students. https://www.portalvs.sk/en/informacie-o-vysokych-skolach/podla-poctu-studentov Accessed January 23, 2021.

Wheaton, B., Muthen, B., Alwin, D.F., Summers, G.F. (1977). Assessing reliability and stability in panel models. Sociological Methodology, 8, 84-136.

Yazici, N., Babalik, A.A. (2016). Determination of environmental awareness of university students: the case of Suleyman Demirel University (SDU). Environmental Earth Sciences, 75(3), 190. 